\title{
Hair straighteners: an approach based on science and consumer profile
}

\author{
Marcella Gabarra Almeida Leite ${ }^{1}$, Wanessa Almeida Ciancaglio Garbossa ${ }^{1}$, Patricia Maria Berardo \\ Gonçalves Maia Campos ${ }^{1 *}$
}

${ }^{1}$ Faculty of Pharmaceutical Sciences of Ribeirao Preto, University of Sao Paulo, Ribeirão Preto, São Paulo, Brazil

\begin{abstract}
Technological progress has allowed women to change their natural hair configuration according to their will. This type of treatment is very popular around the world, even involving the use of prohibited chemicals, such as formaldehyde. Studies of hair characterization, straighteners and toxic evaluation are available in the literature, although few studies have evaluated the consumer profile or the current legislation of Brazil and the European Union (EU) and its influence on the consumption of hair straighteners. Previous studies from our research group have shown that hair care is essential for the quality of life and well-being of women. Within this context, the present study aimed to evaluate the profile of Brazilian hair straightener consumers, as well as the legislation of Brazil and the EU and its influence on the use of these products. The consumer profile was evaluated by applying questionnaires and the legislation was examined using documental and bibliographic exploratory research. The results provided a full understanding of the current legislation of Brazil and its similarities to EU legislation. It was observed that over $50 \%$ of Brazilians currently use or have previously used hair straightener products, even persons who do not have curly hair, suggesting that straight hair is more attractive for today's society. Although the study participants consider the current legislation to be important, over $40 \%$ do not know the active ingredients present in the hair straightener they use. Finally, the legislation is not considered in terms of the daily hair treatment routine, with the esthetic result being more important to the consumer.
\end{abstract}

Keywords: Hair straighteners. Brazilian legislation. European legislation. Consumer profile. Formaldehyde. Glyoxylic acid.

\section{INTRODUCTION}

According to Franbourg (2003), human hair is categorized into three major groups based on ethnic origin, i.e., Asian, Caucasian and African. African hair has a high degree of irregularity in fiber diameter along the hair shaft with an elliptic section. Its fiber has a shape resembling a twisted oval rod, whereas Caucasian and Asian hair is more cylindrical. African hair generally has less tensile strength and breaks more easily than Caucasian and Asian hair. African hair is more difficult to comb than Caucasian and Asian hair because of its extremely curly configuration and has a lower moisture content than Caucasian hair (Berivan et al., 2008).

Humans carry an inherited genetic code that reflects

*Correspondence: P. M. B. G. Maia Campos. Departamento de Ciências Farmacêuticas, Faculdade de Ciências Farmacêuticas de Ribeirão Preto, Universidade de São Paulo. Av. do Café S/N - Monte Alegre. Rib. Preto - SP

- Brasil. 14040-903. Telefone +55 163315 4307. E-mail: pmcampos@usp.br on their hair shape, color, thickness, strength, elasticity, and brightness. These characteristics, however, can be modified by environmental conditions and chemical treatments (Ralph, True, 2009).

Women have been using several materials and methods to change the appearance of their hair. Technological progress in terms of hair straightening processes has allowed women to change their natural hair configuration according to their will (Maneli, Smith, Khumalo, 2014; Dias et al., 2007).

One of the most popular, and dangerous, chemical straighteners is formaldehyde, also called Brazilian Keratin. Despite being a prohibited substance at any concentration for hair straightening, formaldehyde is still frequently used all over the world for this purpose because of its lower cost and quick effect, leaving the strands shiny (Miranda-Vilela, Botelho, Muehlmann, 2014).

Within this context, the development of hair straighteners with active ingredients not based on 
formaldehyde, that are safe and effective, has been a challenge for the scientific community.

Carboxylic acids have attracted attention in the development of hair care products for various reasons. Glyoxylic acid is an active ingredient that has been studied for hair straightening (Boga et al., 2014). Leite and Maia Campos (2017), showed that Glyoxylic acid presents good efficacy of straightening, being better than formaldehyde. Its use has been legalized in the US by the Food and Drug Administration (FDA) and in Europe by the European Medicines Agency (EMA), but in Brazil, where there is great interest in straighteners, the Brazilian Health Surveillance Agency (ANVISA) is still discussing the use of this product (ANVISA, 2016a).

The $\mathrm{pH}$ of use of glyoxylic acid as a hair straightener, is an important topic of discussion, considering that products with $\mathrm{pH}$ values lower than 2,0 and higher than 11,5 are considered dangerous with corrosive potential (ANVISA, 2012a, ANVISA, 2012b; ECHA, 2014). This ingredient usually is used in very low $\mathrm{pH}$ values, which have been considered more effective for the straightening process, due to its $\mathrm{pKa}$ value that is 3,3 .

Studies of hair characterization, straighteners and toxic evaluation are available in the literature, although few studies have evaluated the consumer profile or the current legislation of Brazil and the European Union (EU) and its influence on the consumption of hair straighteners. Previous studies by our research group have shown that hair care is essential for the quality of life and well-being of women since hair plays a significant role in the body image of women (Leite et al., 2015).

The appearance of hair is an important aspect: long and shiny hair reflects health and physical appeal. Healthy hair expresses a complete and attractive person and often symbolizes youth (McMichael, 2003).

Thus, the objective of the present study was to contribute to a full understanding of the profile of Brazilian hair straightener consumers and of the Brazilian and EU legislation and its influence on the use of these products.

\section{MATERIAL AND METHODS}

\section{Bibliographic and documentary exploratory research}

The Brazilian Cosmetic Legislation was examined using Bibliographic and Documentary Exploratory Research in comparison to the EU legislation (Raupp, Beuren, 2003; Sá-Silva, Almeida, Guindani, 2009).

Exploratory Research was chosen in order to obtain a broad view of the subject under study (Gil, 2008), i.e., the Cosmetic Legislation of Brazil, the EU and the US). In addition, according to Raupp and Beuren (2003), this research is defined as an initial survey during which the researchers observe any important information and seek to understand more about the subject.

\section{Investigation of the profile of hair straightener consumers}

The consumer profile was evaluated by applying a questionnaire developed for this purpose, with the aim to reach the most extensive possible portion of the Brazilian population. For this, the developed questionnaire was applied online (google docs). This way we obtained responses from people of all regions of Brazil, but in São Paulo state the number of responses were more pronounced. The questionnaire contained multiple choice questions, which allowed the evaluation of phototype according to the classification of Pathak and Fitzpatrick (1993):

Phototype I - always burns, never tans (pale peach; blond or red hair; blue eyes; freckles).

Phototype II - usually burns, tans minimally (peach; fair; blond or red hair; blue, green, or hazel eyes)

Phototype III - sometimes mild burn, tans uniformly (light brown; fair with any hair or eye color)

Phototype IV - burns minimally, always tans well (moderate brown)

Phototype $V$ - very rarely burns, tans very easily (dark brown)

Phototype VI - never burns, always tans (deeply pigmented dark brown to darkest brown)

A classification was also developed to evaluate the hair types of the study participants:

Type I - straight, normal or dry, thick, strong and without frizz

Type II - straight, oily, fine, weak and with frizz

Type III - wavy, normal or dry, thick, strong and with frizz Type IV - wavy, oily, fine, weak and with frizz Type $V$-curly, normal or dry, fine, weak and with frizz

The authors evaluated the percentage of volunteers who use hair straighteners, as well as the chemicals present in these products, and also determined whether the current legislation influences the choice of hair straighteners.

The following equation (equation 1) was used to calculate the number of participants (n) necessary for the study (Miot, 2011).

$$
n=\frac{N \cdot Z^{2} \cdot p \cdot(1-p)}{Z^{2} \cdot p \cdot(1-p)+e^{2} \cdot(N-1)}
$$




\section{RESULTS AND DISCUSSION}

\section{Bibliographic and documentary exploratory research}

Table I shows the results of Bibliographic and Documentary Exploratory Research.

According to the survey carried out (Table I), it can be seen that the Brazilian cosmetic legislation presents some differences when compared to EU legislation, even though the Brazilian legislation was based on the EU legislation. In both cases, the regulation process is described in their respective embracing cosmetics legislation (ANVISA, 2015; UE, 2009), although there is no specific legislation about the topic under study. This process is faster in the EU since it can be done electronically and the product can be marketed immediately after finishing the online process (UE, 2009).

Hair straighteners in Brazil are categorized as grade 1 and grade 2, without and with registration. The grade 1 cosmetics are products without specific purpose and the regularization process can be done through ANVISA's website. The grade 2 cosmetics have specific purpose and it is necessary a safety and efficacy study for regularization. Sunscreens, hair dyes, insect repellent, hands antiseptic gel and hair straighteners are classified as grade 2 cosmetic products with registration. Thus, in order to regularize them, it is necessary to send all documents, including safety and efficacy studies, to ANVISA by mail, and the product can only be commercialized after evaluation by the Brazilian Health Surveillance Agency - ANVISA and publication of the registration approval in the Official Gazette (ANVISA, 2015).

According to ABIHPEC (2016), ANVISA currently takes approximately 4 months to evaluate and approve or reject the request. This deadline for the hair straightener cosmetic Industry can impact on financial loss or delay for the reimbursement of Research and Development (R\&D) projects. According to Wacker et al. (2016), it is important to have a balance between regulation and innovation, so that R\&D of innovative cosmetic products is not prevented and consumer health is not impaired.

The documents requested for regularization are similar in Brazil and the EU. However, the time for document presentation is different, since the EU requires specifications and toxicological data to be added to a single standard report, which must be organized and maintained in the company for health audit, from the online notification (UE, 2009). In Brazil, despite the need to provide information, there is no standard of presentation, a fact that can impair the health audit.

Furthermore, the Brazilian legislation does not require a detailed description of nanomaterials, which may impact on consumer's safety. Finally, it was observed that the active ingredients accepted for hair straighteners differ between legislations.

According to the 2009 Cosmetic Ingredient Review (CIR), ammonium thioglycolate, butyl thioglycolate, calcium thioglycolate, ethanolamine thioglycolate, ethyl thioglycolate, glyceryl thioglycolate, isooctyl

TABLE I - Comparison of the main topics of the Brazilian and EU legislation about hair straighteners

\begin{tabular}{lcc}
\hline & Brazil & European Union \\
\hline $\begin{array}{l}\text { Specific legislation about hair } \\
\text { straighteners }\end{array}$ & There is no specific legislation & There is no specific legislation \\
\hline
\end{tabular}

RDC 7/2015, about cosmetic product regularization

(ANVISA, 2015)

Current legislation about hair straighteners
RDC 3/2012, about restriction of ingredients of cosmetic products (ANVISA, 2012b)

RDC 83/2016, about prohibited ingredients of cosmetic products (ANVISA, 2016b)

Grade 2 cosmetic product with Categorization of hair straighteners for regularization registration: hair straightening product

(ANVISA, 2015)
Regulation (EC) 1223/2009 of cosmetic products, including restricted and prohibited ingredients (UE, 2009)
Cosmetic product: hair straightening products (UE, 2009) 
TABLE I - Comparison of the main topics of the Brazilian and EU legislation about hair straighteners (cont.)

\begin{tabular}{|c|c|c|}
\hline & Brazil & European Union \\
\hline & Cosmetic product category & Cosmetic product category \\
\hline & Company's name and address & Company's name and address \\
\hline & Technical manager name & Technical manager name \\
\hline & Country of origin, for imported products & Country of origin, for imported products \\
\hline & & $\begin{array}{l}\text { Presence of nanomaterial description, } \\
\text { including chemical identification and } \\
\text { exposure conditions }\end{array}$ \\
\hline & & $\begin{array}{l}\text { Name and CAS number of substances } \\
\text { presumed to have carcinogenic, mutagenic } \\
\text { and toxic to reproduction potential }\end{array}$ \\
\hline & $\begin{array}{l}\text { Formulation with the ingredient's } \\
\text { functions and concentrations }\end{array}$ & $\begin{array}{l}\text { Formulation with the ingredient's } \\
\text { functions and concentrations }\end{array}$ \\
\hline Necessary information for the & Original label & Original label \\
\hline
\end{tabular}

regularization of hair straighteners according to the respective legislation

\section{Active ingredients allowed for hair straighteners}

\begin{tabular}{c}
\hline $\begin{array}{c}\text { Physicochemical and microbiological } \\
\text { specifications of the finished product }\end{array}$ \\
\hline $\begin{array}{l}\text { Physicochemical and microbiological } \\
\text { specifications of the ingredients (only } \\
\text { available from the company) }\end{array}$ \\
$\begin{array}{c}\text { Packaging specifications (only available } \\
\text { from the company) }\end{array}$ \\
\hline Stability data \\
\hline $\begin{array}{c}\text { Safety data (only available in the } \\
\text { company) }\end{array}$ \\
\hline Manufacturing process (only available \\
from the company) \\
\hline Efficacy data (only available from the \\
company)
\end{tabular}

According to ANVISA's information (ANVISA, 2016a), prohibitive list (ANVISA, 2016b) and restrictive list (ANVISA, 2012b)

Thioglycolic acid, including salts and esters

Sodium hydroxide

Potassium hydroxide

Calcium hydroxide

Lithium hydroxide

Guanidine hydroxide

Inorganic sulphites and bisulfites
Product Safety Report including toxicologic profile, physicochemical and microbiological specifications of the ingredients and finished product, stability data and specifications, and impurities of packaging (only available from the company)

Manufacturing process
(only available from the company)
$\begin{gathered}\text { Efficacy data (only available from the } \\ \text { company) }\end{gathered}$

According to the EU inventory (UE, 2006):

Butyl thioglycolate Ammonium thiodiglycolate Ethanolamine thioglycolate Ethyl thioglycolate Glyceryl thioglycolate Isooctyl thioglycolate Isopropyl thioglycolate Magnesium thioglycolate Mercaptopropionic acid Methyl thioglycolate Potassium thioglycolate Strontium thioglycolate Thioglycerin Thioglycolic acid Thiolactic acid thioglycolate, isopropyl thioglycolate, magnesium thioglycolate, methyl thioglycolate, potassium thioglycolate, sodium thioglycolate and thioglycolic acid are considered to be safe ingredients for hair straightenes, concentrations up to $15,2 \%$ (as thioglicolic acid) (Burnett et al., 2009). 
The Brazilian legislation does not include detailed information about thioglycolic acid salts and esters that can be used as active ingredients in hair straighteners, a fact that may can compromise the safety of these products. Complementing these data, the 2016 CIR safety report showed that sodium hydroxide, potassium hydroxide and calcium hydroxide are also safe as active ingredients for hair straighteners within the recommended conditions of use and with minimum contact with the skin (CIR, 2016).

Other substances also accepted as active ingredients for hair straighteners by the Brazilian legislation are inorganic sulfites and bisulfites (ANVISA, 2016b), although they are also not described in detail. Among these substances, the 2003 CIR safety report showed that sodium sulfite, potassium sulfite, sodium bisulfite, sodium metabisulfite and potassium metabisulfite are safe for use in cosmetic products (Nair, Elmore, 2003). The other ingredients accepted by the Brazilian and EU legislation are not present in the safety reports published by the CIR or European Chemicals Agency (ECHA), agencies recognized internationally for safety evaluation of cosmetic ingredients. Scientific articles and regulatory reports are currently available about some active ingredients of hair straighteners not mentioned in these databases, but they are still insufficient.

According to Dias (2015), guanidine hydroxide is a less irritating active ingredient of hair straighteners compared to sodium hydroxide, although there is a lack of conclusive studies about its use.

Lithium hydroxide is present in the ECHA list, although it is not intended for use as a hair straightener or as any other cosmetic product (ECHA, 2016b). An opinion of the Scientific Committee on Cosmetic and Non-food Products published in 2000 has reported the possibility of its use as a hair straightener without detailing its safety (SCCNFP, 2000). However, the new EU legislation does not include lithium hydroxide in the inventory of cosmetic ingredients (Table I).

According to the ECHA, the IUPAC name of the ingredient mercaptopropionic acid is thiolactic acid, i.e. the two names refer to the same substance (ECHA, 2016a). No safety report has been published by the ECHA for the use of this ingredient in cosmetics. However, a study conducted on a limited number of subjects has reported that this acid and its ammonium salt cannot be considered allergenic, but they are unstable and potentially irritating (Uter et al., 2002).

Data about the safety of straightener ingredients are also lacking for strontium thioglycolate and thioglycerin, with no safety report, regulatory information or scientific articles for the evaluation of theur safety and efficacy.

\section{Hair straightener consumer profile research}

The number (n) of participants calculated for the consumer profile research (equation 1) was 254, but only 183 responses to the questionnaire were obtained. Although the ideal $n$ was not reached, the results obtained were relevant for the understanding of a topic still unexplored in the scientific literature.

The results of the consumer's profile research are presented in Figures 1 to 6 . According to the data obtained with the questionnaire, most participants had phototypes II, III and IV and hair classified as wavy (type III and IV) and curly (type V). It can be observed that Brazilian women of similar phototype (Caucasian) have a wide diversity of hair types, reflecting the miscegenation of the Brazilian population.

Over $50 \%$ of the volunteers currently use hair straightener products $(55.7 \%)$ or have previously used them $(32.8 \%)$. The reasons reported to justify the importance of the use of hair straighteners are aesthetic appearance, well-being, and practicality, although $11 \%$ of the participants do not believe that this type of treatment is important.

It is interesting to note that almost $70 \%(67.2 \%)$ of the participants reported considering the current legislation in the choice of the hair straightener products they use, although $41.8 \%$ reported not knowing the active

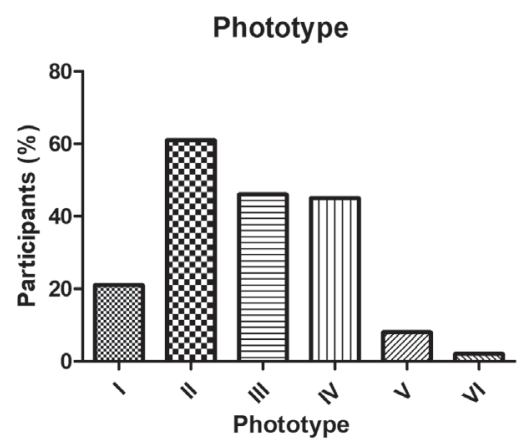

FIGURE 1 - Phototype of the participants.

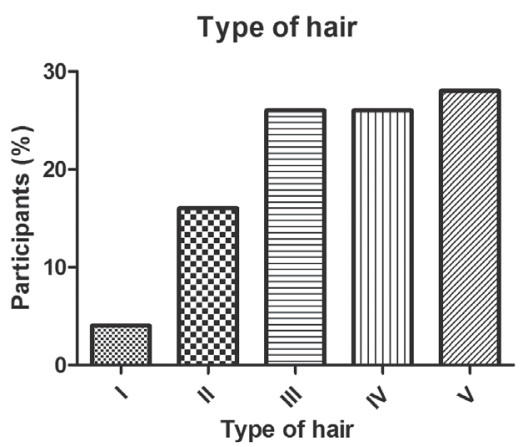

FIGURE 2 - Type of hair of the participants. 


\section{Do you use hair straightener products?}

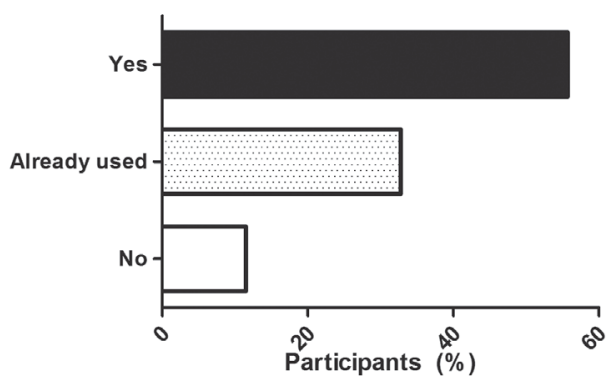

FIGURE 3 - Percentage of participants that use hair straightener products.

Why do you consider the use of hair straighteners important?

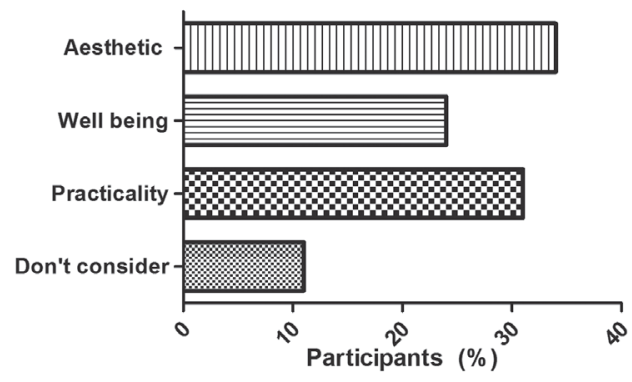

FIGURE 4 - Percentage of participants that consider the use of hair straighteners important.

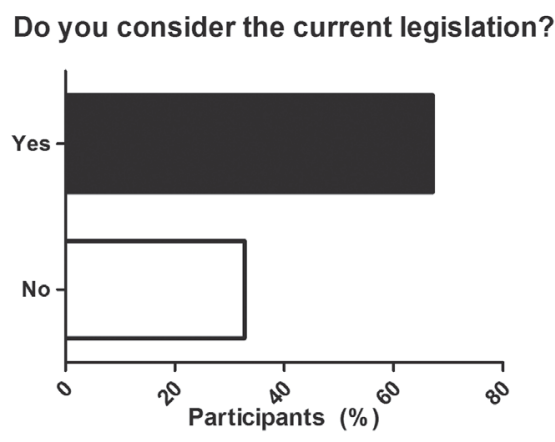

FIGURE 5 - Percentage of participants that consider the current legislation.

What is the active ingredient on your hair straightener product?

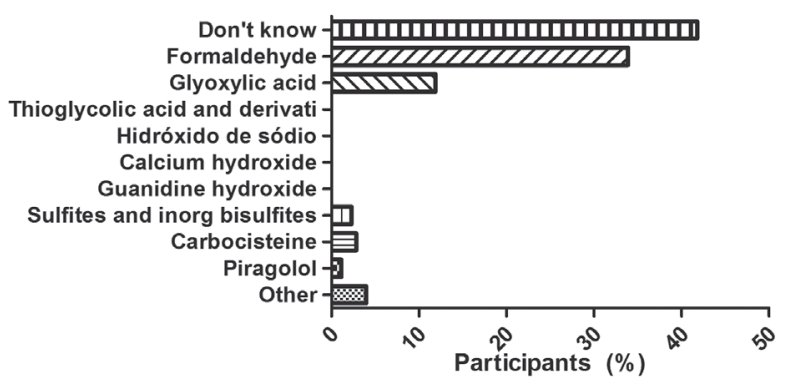

FIGURE 6 - Active ingredients reported in the hair straightener products. ingredients in the products they use and $33.9 \%$ reported that they use products with formaldehyde, considered illegal by the Brazilian legislation. In addition, $11.9 \%$ reported that they use glyoxylic acid, an active ingredidient that has not yet been legalized by ANVISA.

The design and development of this study permitted us to conclude that the Brazilian cosmetic legislation concerning hair straighteners differs from the EU legislation regarding the regularization process, the necessary documents and the active ingredients allowed. The current Brazilian regularization process for hair straighteners has a negative impact on the marketing and the financial return of the $R \& D$ projects. On the other hand, this process can preserve the consumer since it allows the marketing of safe and effective products.

According to the study of the consumer profile, the great majority of the female population uses or has already used hair straighteners, even when the consumer does not have curly hair. The participants reported that straight hair is more attractive and more practical for their daily routine.

Although the volunteers report worrying about the current legislation, most of them do not know the active ingredients of the products they use, nor do they report the use of products with formaldehyde. Thus, it is possible to conclude that the consumers do not really consider the legislation regarding their daily routine of hair treatment, giving priority to the aesthetic result.

Finally, the present study indicates the need for research about the safety and efficacy of hair straighteners.

\section{REFERENCES}

Associação Brasileira da Indústria de Higiene Pessoal, Perfumaria e Cosméticos. ABIHPEC. Legislação harmonizada de cosméticos: quão longe quão perto estamos. 2016. [cited 2016 Oct 20]. Available from: https://www.youtube.com/ watch? $=$ cZfpYYnn808.

Agência Nacional de Vigilância Sanitária. ANVISA. Orientações sobre alisantes. 2016a. [cited 2016 Oct 20]. Available from: http://portal.anvisa.gov.br/alisantes.

Agência Nacional de Vigilância Sanitária. ANVISA. Guia para avaliação de segurança de produtos cosméticos. 2012a. [cited 2017 Sep, 05]. Available from: http://portal.anvisa.gov.br/ documents/106351/107910/Guia+para+Avalia\%C3\%A7\%C3 $\% \mathrm{~A} 3 \mathrm{o}+\mathrm{de}+$ Seguran $\% \mathrm{C} 3 \% \mathrm{~A} 7 \mathrm{a}+\mathrm{de}+$ Produtos $+\mathrm{Cosm} \% \mathrm{C} 3 \% \mathrm{~A}$ 9ticos/ab0c660d-3a8c-4698-853a-096501c1dc7c. 
Agência Nacional de Vigilância Sanitária. ANVISA. RDC nº 3, de 20 de Janeiro de 2012b. Aprova o Regulamento Técnico "Listas de Substâncias que os Produtos de Higiene Pessoal, Cosméticos e Perfumes Não devem conter exceto nas condições e com as restrições estabelecidas" e dá outras providências. Brasília (DF): Ministério da Saúde; 2012. [cited 2016 Oct 20]. Available from: http://portal.anvisa.gov.br/wps/wcm/connect/ f3234d804aee3e39b747bfa337abae9d/Resolu\%C3\%A7\%C3 $\% \mathrm{~A} 3 \mathrm{o}+\mathrm{RDC}+\mathrm{N} \% \mathrm{C} 2 \% \mathrm{BA}+03+\mathrm{de}+20+\mathrm{de}+$ janeiro $+\mathrm{de}+2012$. pdf?MOD=AJPERES.

Agência Nacional de Vigilância Sanitária. ANVISA. RDC n ${ }^{\circ}$ 7, 10 de Fevereiro de 2015. Dispõe sobre os requisitos técnicos para a regularização de produtos de higiene pessoal, cosméticos e perfumes e dá outras providências. Brasília (DF): Ministério da Saúde; 2015. [cited 2016 Sept 21]. Available from: http://www. anvisa.gov.br/areas/coges/legislacao/2015/RDC_07_2015.pdf.

Agência Nacional de Vigilância Sanitária. ANVISA. RDC n ${ }^{\circ}$ 83, de 17 de Junho de 2016. Dispõe sobre o "Regulamento Técnico MERCOSUL sobre lista de substâncias que não podem ser utilizadas em produtos de higiene pessoal, cosméticos e perfumes" e dá outras providências. Brasília (DF): Ministério da Saúde; 2016b. [cited 2016 Oct 20]. Available from: http:// portal.anvisa.gov.br/documents/10181/2859796/\%281\%29R DC_83_2016.pdf/ab636c42-418a-4967-bb1f-5c8c9716e2f7.

Burnett CL, Bergfeld WF, Belsito DV, Klaassen CD, Marks JG Jr, Shank RC, et al. Final amended report on the safety assessment of ammonium thioglycolate, butyl thioglycolate, calcium thioglycolate, ethanolamine thioglycolate, ethyl thioglycolate, glyceryl thioglycolate, isooctyl thioglycolate, isopropyl thioglycolate, magnesium thioglycolate, methyl thioglycolate, potassium thioglycolate, sodium thioglycolate, and thioglycolic acid. Int J Toxicol. 2009;28(4 Suppl):68-133.

Berivan E, Havitciogluu H, Aktan S, Karakus N. Biomechanical properties of human hair with different parameters. Skin Res Technol. 2008;14(2):147-151.

Boga C, Taddei P, Micheletti G, Ascari F, Ballarin B, Morigi $\mathrm{M}$, et al. Formaldehyde replacement with glyoxylic acid in semipermanent hair straightening: a new and multidisciplinary investigation. Int J Cosmet Sci. 2014;36(5):459-470.

CIR. Safety assessment of inorganic hydroxides as used in cosmetics. 2016. [cited 2016 Oct 24]. Available from: http:// online.personalcarecouncil.org/ctfa-static/online/lists/cir-pdfs/ FR703.pdf.
Dias MFRG. Hair cosmetics: an overview. Int J Trichology. 2015;7(1):2-15.

Dias TCDES, Baby AR, Kaneko TM, Velasco MVR. Relaxing/ straightening of Afro-ethnic hair: historical overview. J Cosmet Dermatol. 2007;6(1):2-5.

European Chemicals Agency. ECHA. 2-mercaptopropionic acid. 2016a. [cited 2016 Oct 25]. Available from: https://echa. europa.eu/substance-information/-/substanceinfo/100.001.097.

European Chemicals Agency. ECHA. Lithium hydroxide. 2016b. [cited 2016 Oct 25]. Available from: https://echa.europa. eu/substance-information/-/substanceinfo/100.013.804.

European Chemicals Agency. ECHA. Skin irritation/corrosion, 2014a. [citad 2017 Sep 05]. Available from: https://echa. europa.eu/documents/10162/13643/ir_csa_r7a_irritation_ peg_draft_201410_en.pdf/325de5d2-4c79-4755-83d19a184f81218a.

Franbourg A, Hallegot P, Baltenneck, C, Toutain A, Leroy F. Current research on ethnic hair. Journal of the American Academy of Dermatology 2001;48(6):115-119.

Leite MGA, Favaretto G, Martini APM, Maia Campos PMBG. Characterization of aging hair and its influence in quality of life. Biomed Biopharm Res. 2015;12(1):79-89.

Leite MGA, Maia Campos PBG. Mechanical characterization of curly hair when treated with non conventional hair straighteners. Skin Res Technol. 2017;23(4):539-544.

Gil AL. Métodos e técnicas de pesquisa social. São Paulo: Atlas; 2008. 200 p.

Maneli MH, Smith P, Khumalo NP. Elevated formaldehyde concentration in "Brazilian keratin type" hair-straightening products: A cross-sectional study. J Am Acad Dermatol. 2014;70(2):276-280.

Mcmichael AJ. Ethnic hair update: past and present. J Am Acad Dermatol. 2003;48(6 Suppl):130-133.

Miranda-Vilela AL, Botelho AJ, Muehlmann LA. An overview of chemical straightening of human hair: technical aspects, potential risks to hair fibre and health and legal issues. Int $\mathrm{J}$ Cosmet Sci. 2014;36(1):2-11.

Miot HA. Tamanho da amostra em estudos clinicos e experimentais. J Vasc Bras. 2011;10(4):275-278. 
Nair B, Elmore AR. Final report on the safety assessment of sodium sulfite, potassium sulfite, ammonium sulfite, sodium bisulfite, ammonium bisulfite, sodium metabisulfite and potassium metabisulfite. Int J Toxicol. 2003;22(Suppl 2):63-88.

Pathak MA, Fitzpatrick TB. Preventive treatment of sunburn, dermatoheliosis and skin cancer with sun-protective agents. In: Fitzpatrick TB, Eilsen AZ, Wolff K, Freedberg IM, Austen KF. Dermatology in general medicine. 4th ed. New York: McGrawHill, 1993; p. 1689-1716.

Ralph M, True B. Oxidative stress in ageing of hair. Int J Thricol. 2009;1(1):6-14.

Raupp FM, Beuren IM. Metodologia da pesquisa aplicável às ciências sociais. In: Beuren IM. Como elaborar trabalhos monográficos em contabilidade: teoria e prática. São Paulo: Atlas; 2003. p. 76-97.

Sá-Silva JR, Almeida CD, Guindani JF. Documentary research: theoretical and methodological clues. Rev Bras Hist Ciências Soc. 2009;1(1):1-15.

SCCNFP. Opinion concerning lithium hydroxide and calcium hydroxide, modification to entries $n^{\circ} 15 \mathrm{~b}$ and $15 \mathrm{c}$ in Annex III to directive $76 / 768 / \mathrm{ECC}$ on cosmetic products adopted by the SCCNFP during the 12th Plenary Meeting of 3 may 2000. 2000. [cited 2016 Oct 24]. Available from: http://ec.europa. eu/health/scientific_committees/consumer_safety/opinions/ sccnfp_opinions_97_04/sccp_out117_en.htm.
UE. Comissão das Comunidades Europeias. Decisão da Comissão 2006/257/EC de 9 de Fevereiro de 2006 que estabelece um inventário e uma nomenclatura comum dos ingredientes utilizados nos produtos cosméticos. Official Journal of the European Union; 2006. p. 1-528. [cited 2016 Oct 20]. Available from: http://eur-lex.europa.eu/legal-content/EN/TXT/ $\mathrm{PDF} /$ ?uri=CELEX:32006D0257\&from=EN.

UE. Parlamento Europeu e o Conselho da União Europeia. Regulamento (CE) no 1223/2009 do Parlamento Europeu e do Conselho de 30 de Novembro de 2009 relativo aos produtos cosméticos. Official Journal of the European Union; 2009. p.59209. [cited 2015 Feb 04]. Available from: http://eur-lex.europa. eu/legal-content/PT/TXT/PDF/?uri=CELEX:32009R1223\&qi $\mathrm{d}=1422448426639 \&$ from $=$ PT.

Uter W, Geier J, Pirker C, Aberer W, Kränke B, Richter G et al. Ammonium thiolactate and thiolactic acid: important hairdressers' allergens? Contact Dermatitis. 2002;46(4):242243.

Wacker MG, Proykova A, Mendes Lima Santos G. Dealing with Nanosafety around the Globe-Regulation vs. Innovation. International Journal of Pharmaceutics. 2016;509(1-2):95-106.

Received for publication on $01^{\text {st }}$ August 2017 Accepted for publication on $07^{\text {th }}$ October 2017 